\title{
Role of interventional radiology in pudendal neuralgia: a description of techniques and review of the literature
}

\section{Ruolo della radiologia interventistica nella nevralgia del nervo pudendo: descrizione della tecnica e revisione della letteratura}

\author{
E. Fanucci • G. Manenti • A. Ursone • N. Fusco • I. Mylonakou • S. D’Urso • G. Simonetti \\ Department of Imaging Diagnostics, Molecular Imaging, Interventional Radiology and Radiotherapy, Policlinico Universitario \\ "Tor Vergata", Viale Oxford 81, 00133 Rome, Italy \\ Correspondence to: E. Fanucci; G. Manenti, Tel: +39-06-20902374, Fax: +39-06-20902404, e-mail: guggi@ tiscali.it; \\ ezio.fanucci@libero.it
}

Received: 15 January 2008 / Accepted: 18 July 2008 / Published online: 10 March 2009

(C) Springer-Verlag 2009

\begin{abstract}
Purpose. The authors sought to evaluate indications, technical feasibility and clinical efficacy of computed tomography (CT)-guided pudendal nerve infiltration in patients with chronic anoperineal pain by reviewing the role of the CT technique in their personal experience and in the recent interventional literature.

Materials and methods. Twenty-eight women, mean age 50 years, and with a diagnosis of pudendal neuralgia on the basis of clinical and electromyographic criteria were enrolled in the study. CT-guided pudendal nerve injections were performed during three consecutive sessions held 2 weeks apart. In each session, patients received two percutaneous injections: one in the ischial spine, and the other in the pudendal (Alcock's) canal.

Results. One patient dropped out of the study after the first session. At clinical assessment, 24h h after treatment, 21/27 patients reported significant pain relief. At follow-up at 3, 6, 9 and 12 months, 24/27 patients reported a $\geq 20 \%$ improvement in the Quality of Life (QOL) index. Conclusions. In pudendal nerve entrapment, CT-guided perineural injection in the anatomical sites of nerve impingement is a safe and reproducible treatment with a clinical efficacy of $92 \%$ at 12 months.
\end{abstract}

Keywords Neuralgia $\cdot$ Pudendal nerve block $\cdot$ Alcock's canal entrapment $\cdot$ Computed tomography guidance

\section{Riassunto}

Obiettivo. Valutare le indicazioni, la fattibilità tecnica e l'efficacia clinica della infiltrazione TC guidata del nervo pudendo in pazienti con sindrome ano-perineale nevralgica effettuando una revisione del ruolo della tecnica TC nella letteratura recente in ambito interventistico.

Materiali e metodi. Ventotto donne con età media 50 anni e diagnosi di nevralgia del pudendo effettuata sulla base di criteri clinici ed elettromiografici, sono state incluse nel nostro studio. Le iniezioni del nervo pudendo sono state eseguite sotto guida TC, in 3 sedute intervallate da 2 settimane. In ogni seduta, sono state effettuate due sessioni di trattamento iniettivo percutaneo, la prima iniezione è stata effettuata a livello della spina ischiatica e la seconda a livello del canale di Alcock.

Risultati. In un caso la procedura è stata interrotta dopo la prima sessione, e pertanto tale paziente è stata esclusa dalla successiva valutazione. Nella valutazione a ventiquattrore post-trattamento è stato riferito un miglioramento qualitativo significativo della sintomatologia dolorosa in 21 casi su 27; in 24 su 27 casi è stato riportato un miglioramento $\geq 20 \%$ dell'indice di qualità della vita (QOL index) nel follow-up clinico a 3, 6, 9 e 12 mesi.

Conclusioni. Nella sindrome da intrappolamento del nervo pudendo, l'iniezione perineurale TC guidata delle sedi anatomiche di conflitto nervoso risulta una procedura sicura e ripetibile con una efficacia clinica nel $92 \%$ dei pazienti trattati nel follow-up a 12 mesi.

Parole chiave Nevralgia $\cdot$ Blocco del nervo pudendo $\cdot$ Intrappolamento nel canale di Alcock · Tomografia computerizzata guidata 


\section{Introduction}

Chronic pelvic pain can be defined as noncyclic pain in the pelvis, anterior abdominal wall below the umbilical line and lumbosacral region and/or glutei that persists continuously for at least 6 months and is sufficiently severe to cause functional disability and/or require nonspecific pharmacotherapy. Although the exact prevalence of chronic pelvic pain in the two genders is unknown, 15\%-20\% of women aged 18-50 years are estimated to be affected [1]. Among men, approximately $8 \%$ of urological examinations and $1 \%$ of primary care consultations are related to chronic pelvic pain [2]. The symptoms of pudendal nerve entrapment overlap considerably with those of chronic nonbacterial prostatitis, the most common symptomatic type of prostatitis. Noncompressive strain injuries of the pudendal nerve are common to pelvic floor dysfunction, chronic constipation and surgical and obstetric trauma [3]. Chronic pelvic pain may occur in a variety of clinical syndromes [4].

The diagnostic and therapeutic roles of interventional radiology have increasingly gained importance in three specific chronic pelvic pain syndromes: pudendal neuralgia, piriformis syndrome and border nerve syndrome (ilioinguinal, iliohypogastric and genitofemoral nerve neuropathy).

Pudendal neuralgia is a clinical entity that was underrecognised and poorly understood for many years [3, 4]. The pudendal nerve is a mixed sensory and motor nerve that arises from the somatic component of sacral nerve roots S2 and S4 on the ventral aspect of the piriformis muscle in the pelvic cavity and crosses the gluteal region, passing through the greater ischiatic foramen into the infrapiriformis canal. It supplies the anus, the urethral sphincters, the pelvic floor and the perineum and is responsible for genital sensitivity. The nerve is accompanied by the internal pudendal artery and is surrounded by a venous plexus (pudendal neurovascular bundle). The pudendal bundle courses around the sacrospinous ligament near to its attachment to the ischial spine, enters the perineum through the lesser ischiatic foramen (Fig. 1) and courses through the ischiorectal fossa and then through the pudendal (Alcock's) canal that is formed by duplication of the obturator fascia on the lateral wall of the ischiorectal fossa. Within the pudendal canal, the nerve gives off two terminal branches: the perineal nerve, and the dorsal nerve of the penis or clitoris. The nerve is prone to entrapment at the level of the ischial spine and within the pudendal canal. At the ischial spine, the nerve is frequently compressed between the sacrospinous and sacrotuberous ligaments. At the level of Alcock's canal, the pudendal nerve may be compressed by the falciform process of the sacrotuberous ligament. If thickened, duplication of the obturator fascia may also contribute to the entrapment $[6,7]$.

\section{Introduzione}

Il dolore pelvico cronico si può definire come dolore nonciclico localizzato alla regione pelvica, alla parete addominale anteriore inferiormente alla linea ombelicale e alla regione lombo-sacrale elo ai glutei, che persiste continuativamente per almeno 6 mesi, di entità sufficiente da causare disabilità funzionale elo richiedere cure farmacologiche generiche. Sebbene la prevalenza del dolore pelvico cronico nella popolazione generale in entrambe $i$ sessi non sia ancora completamente definita, si stima che ne siano affette circa il 15\%-20\% delle donne di età compresa tra i 18 e i 50 anni [1]. Si calcola che negli uomini circa l'8\% delle visite urologiche e l'1\% delle visite mediche generiche siano correlate a dolore pelvico cronico [2]. I sintomi di entrapment del pudendo si sovrappongono infatti considerevolmente con quelli della prostatite cronica non batterica, che è il tipo più comune di prostatite sintomatica. Lesioni da stiramento non compressivo del nervo pudendo sono comuni a varie alterazioni del pavimento pelvico, stitichezza cronica e trauma chirurgico ed ostetrico [3]. Il dolore pelvico cronico si può presentare in varie sindromi cliniche [4].

Il ruolo diagnostico e terapeutico della radiologia interventistica appare di crescente importanza in tre quadri sindromici di dolore pelvico cronico: nevralgia del pudendo, sindrome del piriforme e sindrome "border nerve" (neuropatia iliaco-inguinale, iliaco-ipogastrica $e$ del nervo genito-femorale).

La nevralgia del nervo pudendo è stata un'entità clinica a lungo non riconosciuta o scarsamente identificata [3, 4]. Il nervo pudendo è un nervo misto sensitivo e motorio, derivante dalla componente somatica delle radici del sacro $\mathrm{S} 2$ ed S4 dalla parte ventrale del muscolo piriforme nella cavità pelvica, attraversa la regione glutea passando attraverso il più grande forame ischiatico nel canale infrapiriforme. Provvede all'innervazione anale, degli sfinteri uretrali, del pavimento pelvico, del perineo e della sensibilità genitale. Il nervo è accompagnato dall'arteria pudenda interna ed è circondato da un plesso venoso (fascio neurovascolare pudendo). Il fascio pudendo decorre intorno al legamento sacrospinoso in prossimità della sua inserzione sulla spina ischiatica, entra nel perineo tramite il piccolo foro ischiatico (Fig. 1), decorre nella fossa ischioanale e infine attraversa il canale pudendo (di Alcock) che è costituito dalla duplicazione della fascia otturatoria sulla parete laterale della fossa ischio-anale. All'interno del canale pudendo, il nervo si divide in due rami terminali, costituiti dal nervo perineale e dal nervo dorsale del pene o del clitoride. Il nervo è predisposto all'intrappolamento a livello della spina ischiatica ed all'interno del canale pudendo. Alla spina ischiatica, il nervo può essere compresso di frequente tra i legamenti sacrospinoso e sacrotuberoso. A livello del canale di Alcock, il nervo può essere compresso 


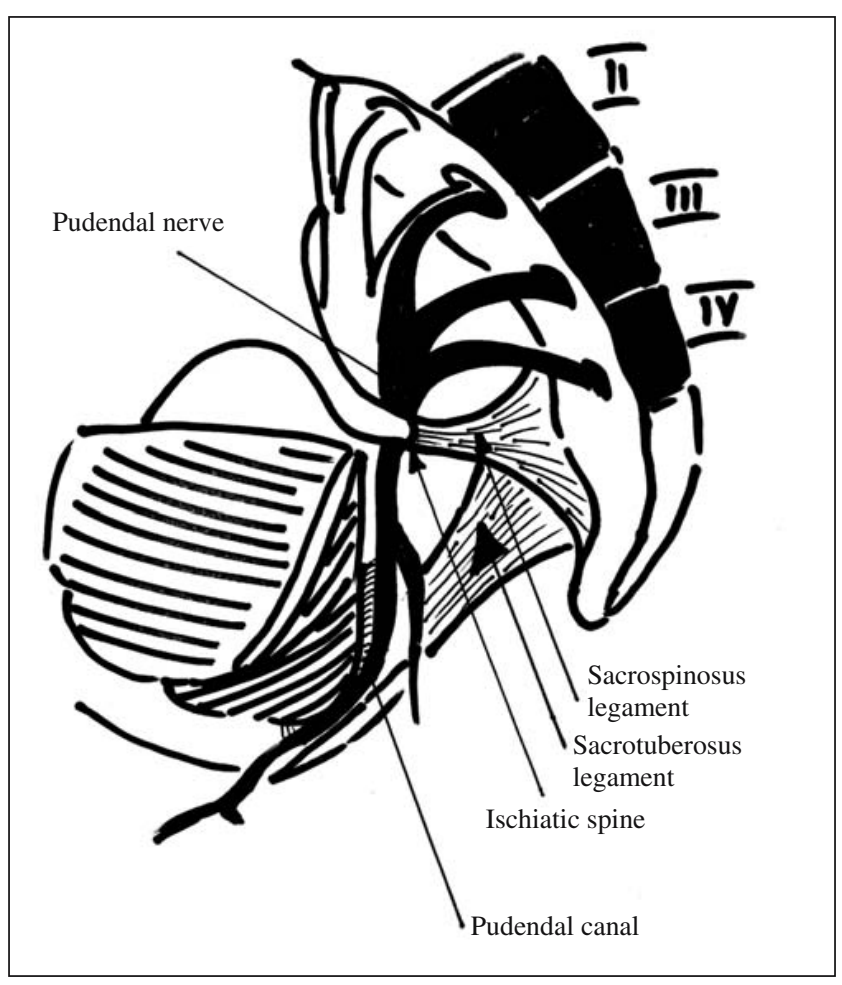

Fig. 1 Pudendal nerve anatomy. Modified from Hough et al [5].

Fig. 1 Anatomia del nervo pudendo. Modificato da Hough et al. [5].

Boisson, in 1966 [8], was the first to suggest that chronic anoperineal pain might be a form of neuropathy, a hypothesis that was later confirmed by others who defined pudendal neuralgia as an entrapment neuropathy $[6,9,10]$. However, although entrapment is certainly the most common cause of pudendal neuralgia, other causes have also been described [11], including peripheral polyneuropathy, postherpetic neuropathy, postactinic neuropathy and neoplastic compression.

Although neurophysiological studies [12] have contributed to the knowledge of the disease, they cannot be regarded as first-line diagnostic investigations. Electroneuromyography (ENMG) has limited sensitivity and specificity in the differential diagnosis between nerve impingement and chronic perineal pain syndrome. ENMG is indicated for determining pudendal motor innervation prior to surgical decompression but not for locating the site of compression or monitoring the surgical procedure [12].

Just as there are no definitive clinical or imaging criteria for diagnosing pudendal neuralgia, neither is there a standard therapeutic approach, with conservative treatment, nerve block, decompressive surgery and neuromodulation all having shown to be useful [13]. Interventional radiology is proposed as an effective technique for percutaneous infiltration of the pudendal nerve under computed tomography (CT), ultrasound (US) or fluoroscopic guidance. dal processo falciforme del legamento sacrotuberoso. Se ispessita, la duplicazione della fascia otturatoria può anche contribuire essa stessa all'intrappolamento [6, 7].

Boisson [8] suggerì per primo, nel 1966, che la causa del dolore anoperineale cronico potesse essere una neuropatia; altri autori hanno successivamente confermato tale ipotesi, definendo la nevralgia del pudendo come una neuropatia da entrapment [6, 9, 10]. Tuttavia se l'intrappolamento è senza dubbio la causa più frequente di nevralgia del pudendo, altre eziologie sono state descritte [11]: polineuropatia periferica, neuropatia post-erpetica, neuropatia post-attinica, compressione neoplastica.

Anche se gli studi neurofisiologici [12] hanno contribuito alla conoscenza della malattia, non possono essere riconosciuti come indagine diagnostica di prima istanza. Gli studi elettroneuromiografici (ENMG) presentano limitate sensibilità e specificità nella diagnosi differenziale tra lesione nervosa da conflitto e sindrome da dolore perineale cronico. L'esame ENMG è indicato nella definizione della innervazione motoria del territorio di innervazione del pudendo prima della decompressione chirurgica ma non nella localizzazione della sede di compressione o nel monitoraggio intra-operatorio[12].

Se la diagnosi di nevralgia del pudendo non ha criteri diagnostici clinico-strumentali definitivi, altrettanto ̀̀ valido per il suo trattamento. Terapie conservative, blocco del nervo, chirurgia decompressiva e neuromodulazione sono utili nel trattamento della nevralgia [13]. La radiologia interventistica si propone in modo efficace come terapia infiltrativa percutanea del nervo pudendo sotto guida TC, ecografica o fluoroscopica.

Lo scopo del presente lavoro è di descrivere $i$ vantaggi della tecnica di blocco TC guidata del nervo pudendo e confrontarla con altre tecniche di radiologia interventistica imaging-guidate recentemente proposte in letteratura. End point primario dello studio la risoluzione persistente della sintomatologia algica nel periodo di follow-up individuale.

\section{Materiali e metodi}

Nel periodo compreso tra maggio 2006 e gennaio 2008 sono state incluse nel nostro studio prospettico 28 donne con età media 50 anni e diagnosi di nevralgia del pudendo, posta sulla base di criteri clinici ed elettromiografici, con algia significativa e invariata/persistente dopo 6 settimane di terapia conservativa (Tabella 1). La durata media dei sintomi della popolazione trattata è di 29,2 mesi. L'intensità minima del dolore >5/10 VAS score (Visual Analog Pain Scale - livello di dolore riferito a intensità, distress muscolare, spasmo muscolare, interferenza con normali attività quotidiane) per tre giorni consecutivi e dolore posturale intermittente valutato durante test biomeccanico. 
This paper describes the advantages of CT-guided pudendal nerve block and compares it with other imagingguided interventional radiology procedures recently proposed in the literature. The primary end-point of the study was persistent pain relief in the follow-up period.

\section{Materials and methods}

Between May 2006 and January 2008, we recruited 28 women (mean age 50 years) with a diagnosis of pudendal neuralgia based on clinical and electromyographic (EMG) criteria and suffering from persistent significant pain after 6 weeks of conservative therapy (Table 1). The average duration of symptoms was 29.2 months. Minimum pain intensity was a score of $>5 / 10$ on the visual analogue scale (VAS): pain level related to intensity, muscular distress, muscular spasm and interference with normal daily activities for 3 consecutive days and intermittent postural pain assessed with a biomechanical test.
I pazienti (n=28) hanno firmato un consenso informato allo studio precedentemente approvato dalla commissione etica del nostro Policlinico. Tutte le pazienti, con evidenza clinica di dolore cronico inabilitante gravativo non urente e non-ciclico della regione ano-rettale, labbra e perineo sono state sottoposte a RM del rachide lombo-sacrale per escludere la presenza di ernia discale elo impingement radicolare. Lo studio neurofisiopatologico non dimostrava spike di attivazione spontanea dei muscoli paraspinali lombari da patologia radicolare prossimale al ganglio sciatico. Il dolore era esacerbato dalla posizione seduta e attenuato nella posizione ortostatica, clinostatica e nella seduta sul WC.

Tutte le pazienti erano maggiorenni, con un test di gravidanza negativo (6 in età riproduttiva), con un peso corporeo $\geq 50 \mathrm{~kg}$ ed erano stabili da un punto di vista medico sistemico. Il protocollo di trattamento prevede che le inoculazioni siano eseguite in successione a distanza di 15 giorni una dall'altra per 3 volte; in ogni seduta la prima sessione è effettuata a livello della spina ischiatica e la seconda a livello del canale pudendo [14].

Table 1 Patient characteristics

\begin{tabular}{|c|c|c|c|c|c|c|c|}
\hline Subject & Age (years) & $\begin{array}{l}\text { Type of } \\
\text { treatment }^{\mathrm{a}}\end{array}$ & $\begin{array}{l}\text { Time (months) } \\
\text { since symptom } \\
\text { onset }\end{array}$ & $\begin{array}{l}\text { Treatment } \\
\text { side }\end{array}$ & Pain relief & $\begin{array}{l}\text { QOL } \\
\text { index }\end{array}$ & $\begin{array}{l}\text { Follow-up } \\
\text { (months) }\end{array}$ \\
\hline 1 & 28 & AIM+AAC & 24 & Left & Yes & B & 9 \\
\hline 2 & 44 & AIM & 22 & Left & Yes & A & 6 \\
\hline 3 & 35 & AIM & 32 & Right & Yes & A & 3 \\
\hline 4 & 66 & AIM & 13 & Right & Yes & $\mathrm{A}$ & 3 \\
\hline 5 & 46 & $\mathrm{AIM}+\mathrm{AAC}$ & 24 & Left & Yes & A & 3 \\
\hline 6 & 43 & $\mathrm{AIM}+\mathrm{AAC}$ & 17 & Left & Yes & $\mathrm{A}$ & 3 \\
\hline 7 & 32 & AIM & 56 & Right & No & B & 3 \\
\hline 8 & 55 & AIM & 44 & Right & Yes & B & 12 \\
\hline 9 & 39 & AIM & 56 & Left & Yes & $\mathrm{A}$ & 12 \\
\hline 10 & 54 & AIM & 42 & Left & No & $\mathrm{A}$ & 9 \\
\hline 11 & 55 & AIM & 35 & Left & No & $\mathrm{A}$ & 9 \\
\hline 12 & 66 & AIM & 28 & Left & No & $\mathrm{A}$ & 3 \\
\hline 13 & 54 & $\mathrm{AIM}+\mathrm{AAC}$ & 25 & Left/Right & Yes & A & 3 \\
\hline 14 & 63 & AIM & 34 & Right & Yes & A & 3 \\
\hline 5 & $\$ 67$ & AIM & 38 & Right & Yes & A & 3 \\
\hline 16 & 38 & AIM & 44 & Right & Yes & A & 3 \\
\hline 17 & 44 & AIM & 24 & Right & Yes & $\mathrm{A}$ & 3 \\
\hline 18 & 58 & $\mathrm{AIM}+\mathrm{AAC}$ & 15 & Left & No & $\mathrm{A}$ & 3 \\
\hline 19 & 45 & AIM & 18 & Left & Yes & $\mathrm{A}$ & 12 \\
\hline 20 & 37 & AIM & 41 & Left & Yes & $\mathrm{A}$ & 12 \\
\hline 21 & 45 & AIM & 26 & Right & Yes & $\mathrm{A}$ & 12 \\
\hline 22 & 47 & AIM & 23 & Right & Yes & $\mathrm{A}$ & 12 \\
\hline 23 & 59 & AIM & 33 & Right & Yes & $\mathrm{A}$ & 12 \\
\hline 24 & 61 & $\mathrm{AIM}+\mathrm{AAC}$ & 15 & Right & Yes & $\mathrm{A}$ & 12 \\
\hline 25 & 56 & $\mathrm{AIM}+\mathrm{AAC}$ & 11 & Right & Yes & $\mathrm{A}$ & 9 \\
\hline 26 & 48 & $\mathrm{AIM}+\mathrm{AAC}$ & 44 & Right & Yes & A & 12 \\
\hline 27 & 45 & AIM & 22 & Right & Yes & A & 3 \\
\hline 28 & 71 & AIM & 11 & Right & suspended & suspended & suspended \\
\hline
\end{tabular}

${ }^{a} A I M$, anti-inflammatory medications (acetaminophen/ibuprofen) - $A A C$, antidepressants/anticonvulsants (amitriptyline).

$Q O L$, quality of life; ${ }^{\mathrm{b}} \mathrm{Q} \mathrm{QL}$ index $\mathrm{A} \geq 20 \%$; QOL index $\mathrm{B} \leq 20 \%$ 
The study was approved by our hospital's ethics committee, and informed consent was obtained from all patients. Patients with clinical evidence of chronic, disabling, nonburning, noncyclic aching pain in the anorectal, labial and perineal regions underwent magnetic resonance imaging (MRI) of the lumbosacral spine to rule out intervertebral disk herniation and/or radicular impingement. The neuropathophysiological study revealed no spontaneous spike activity of the paraspinal lumbar muscles due to radiculopathy proximal to the sciatic ganglion. Pain was exacerbated by sitting and relieved by standing, lying and sitting on the toilet seat.

All patients were adults, with negative pregnancy tests ( $n=6$ of childbearing age), with a body weight $\geq 50 \mathrm{~kg}$ and systemically stable. The treatment protocol involved three consecutive sessions held 15 days apart. During each session, a first injection was targeted to the ischial spine region and a second to the pudendal canal [14].

With the patient in the prone position, 2.5-mm-thick scans with a pitch of 1 were acquired from the acetabular roof to the pubic symphysis. The scans should allow clear
La paziente è posta in decubito prono; il protocollo impiegato si avvale della acquisizione di scansioni da 2,5 mm, con pitch 1, estese dal tetto dell'acetabolo alla sinfisi pubica. Nelle scansioni devono essere chiaramente identificati la spina ischiatica, i legamenti sacrospinoso e sacrotuberoso ed il fascio pudendo (Fig. 2). Il nervo pudendo sovrasta la spina ischiatica esattamente a livello della inserzione del legamento sacrospinoso, ed è rivestito a questo livello dalla superficie interna del legamento sacrotuberoso, visibile come una linea iperdensa sovrapposta alla parte ventrale del muscolo grande gluteo. Il legamento falciforme appare come struttura iperdensa lungo l'otturatore interno ove il canale pudendo è in posizione ventrale rispetto al legamento falciforme. Previa disinfezione della cute della regione glutea, viene inserito un ago spinale da 22 G per via trans-glutea, verso il fascio pudendo con direzione verticale in corrispondenza della parte caudale della spina ischiatica, evitando il nervo sciatico. Quando la punta dell'ago attraversa il legamento sacro-tuberoso si avverte tipicamente un "click". Posizionata correttamente la punta dell'ago nello spazio interlegamentoso (fra i legamenti

Tabella 1 Caratteristiche dei soggetti

\begin{tabular}{|c|c|c|c|c|c|c|c|}
\hline Pazienti & Età (anni) & $\begin{array}{l}\text { Tipo di } \\
\text { trattamento }^{a}\end{array}$ & $\begin{array}{l}\text { Tempo (mesi) dalla } \\
\text { comparsa dei } \\
\text { sintomi }\end{array}$ & $\begin{array}{l}\text { Lato del } \\
\text { trattamento }\end{array}$ & $\begin{array}{l}\text { Scomparsa } \\
\text { del dolore }\end{array}$ & $\begin{array}{l}\text { Indice } \\
Q O L^{b}\end{array}$ & $\begin{array}{l}\text { Follow-up } \\
\text { (mesi) }\end{array}$ \\
\hline 1 & 28 & $A I M+A A C$ & 24 & Sinistro & si & $B$ & 9 \\
\hline 2 & 44 & AIM & 22 & Sinistro & si & $A$ & 6 \\
\hline 3 & 35 & $A I M$ & 32 & Destro & si & $A$ & 3 \\
\hline 4 & 66 & $A I M$ & 13 & Destro & si & $A$ & 3 \\
\hline 5 & 46 & $A I M+A A C$ & 24 & Sinistro & $s i$ & $A$ & 3 \\
\hline 6 & 43 & $A I M+A A C$ & 17 & Sinistro & si & $A$ & 3 \\
\hline 7 & 32 & AIM & 56 & Destro & no & $B$ & 3 \\
\hline 8 & 55 & $A I M$ & 44 & Destro & si & $B$ & 12 \\
\hline 9 & 39 & AIM & 56 & Sinistro & $s i$ & $A$ & 12 \\
\hline 10 & 54 & AIM & 42 & Sinistro & no & $A$ & 9 \\
\hline 11 & 55 & $A I M$ & 35 & Sinistro & no & $A$ & 9 \\
\hline 12 & 66 & $A I M$ & 28 & Sinistro & no & $A$ & 3 \\
\hline 13 & 54 & $A I M+A A C$ & 25 & Sinistro/Destro & $s i$ & $A$ & 3 \\
\hline 14 & 63 & AIM & 34 & Destro & si & $A$ & 3 \\
\hline 15 & 67 & $A I M$ & 38 & Destro & si & $A$ & 3 \\
\hline 16 & 38 & AIM & 44 & Destro & si & $A$ & 3 \\
\hline 17 & 44 & $A I M$ & 24 & Destro & si & $A$ & 3 \\
\hline 18 & 58 & $A I M+A A C$ & 15 & Sinistro & no & $A$ & 3 \\
\hline 19 & 45 & AIM & 18 & Sinistro & $s i$ & $A$ & 12 \\
\hline 20 & 37 & $A I M$ & 41 & Sinistro & si & $A$ & 12 \\
\hline 21 & 45 & AIM & 26 & Destro & $s i$ & $A$ & 12 \\
\hline 22 & 47 & $A I M$ & 23 & Destro & si & $A$ & 12 \\
\hline 23 & 59 & AIM & 33 & Destro & si & $A$ & 12 \\
\hline 24 & 61 & $A I M+A A C$ & 15 & Destro & si & $A$ & 12 \\
\hline 25 & 56 & $A I M+A A C$ & 11 & Destro & si & $A$ & 9 \\
\hline 26 & 48 & $A I M+A A C$ & 44 & Destro & si & $A$ & 12 \\
\hline 27 & 45 & AIM & 22 & Destro & si & $A$ & 3 \\
\hline 28 & 71 & AIM & 11 & Destro & sospeso & sospeso & sospeso \\
\hline
\end{tabular}

${ }^{a}$ AIM, Trattamento antinfiammatorio (acetaminophen/ibuprofen) - ACC, antidepressivo/anticonvulsionante (aminouryptiline).

$Q O L$, quality of life ${ }^{b}$ Indice $Q O L A \geq 20 \%$; Indice $Q O L B \leq 20 \%$ 

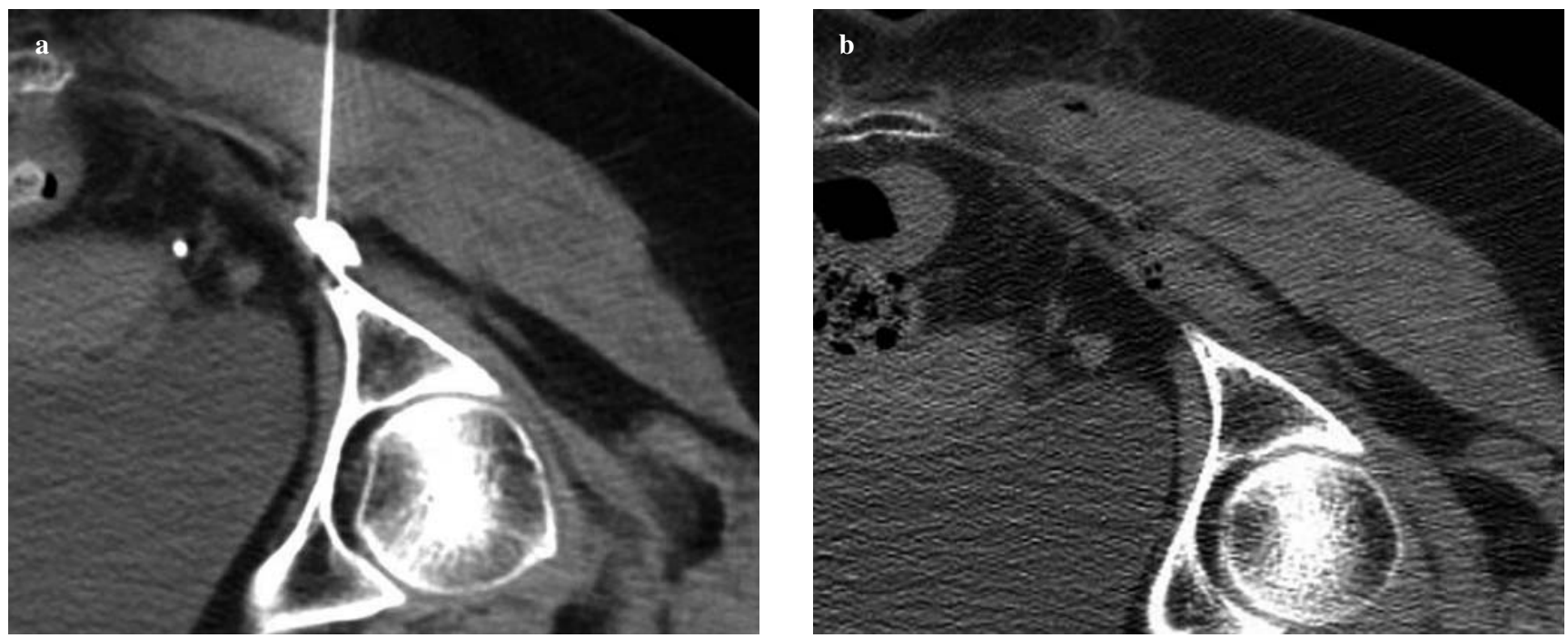

Fig. 2a The needle is placed at the ischial spine. The contrast material shows the nerve outline. b After the needle is removed, a small quantity of air is visible between the sacrospinous and sacrotuberous ligaments.

Fig. 2 a Ago posizionato in corrispondenza della spina ischiatica. Il mezzo di contrasto delimita il profilo del nervo. b Dopo rimozione dell'ago si osserva la presenza di una piccola quantità di gas interposta tra il legamento sacrospinoso e sacrotuberoso.

identification of the ischial spine, sacrospinous and sacrotuberous ligaments and pudendal bundle (Fig. 2). The pudendal nerve crosses the ischial spine exactly at the point where the sacrospinous ligament attaches to the spine, and at this level, it is covered by the inner surface of the sacrotuberous ligament, which appears as a dense linear structure over the ventral portion of the gluteus maximus muscle. The falciform ligament appears as a dense structure along the internal obturator, and the pudendal canal is in a ventral position to the falciform ligament. After the skin of the gluteal region has been disinfected, a 22-gauge spinal needle is inserted transgluteally and advanced towards the pudendal bundle following a vertical direction at the caudal extremity of the ischial spine, with care being taken to avoid the sciatic nerve. When the needle tip crosses the sacrotuberous ligament, a "click" is typically felt. Once the needle tip is correctly placed in the interligamentous space (between the sacrospinous and sacrotuberous ligaments, as close as possible to the caudal portion of the ischial spine), $0.75 \mathrm{ml}$ of diluted contrast agent $(5 \%$ Iomeron $300 \mathrm{mg} / \mathrm{ml}$, Bracco, Milan, Italy) is injected, which should appear to surround the pudendal bundle in the interligamentous space. This is followed by an injection of a mixture of methylprednisolone $(1 \mathrm{ml}$ Depo-Medrol $40 \mathrm{mg} / \mathrm{ml}$ solution, Pfizer, New York, NY, USA) and lidocaine (1 ml 2\% $200 \mathrm{mg} / 10$ $\mathrm{ml}$ solution, Bioindustria LIM, Novi Ligure, Italy). Lidocaine, a long-acting anaesthetic, numbs the skin in the pudendal nerve area and serves to indicate the exact location of the nerve block. Cortisone ensures a long-term response in view of both its anti-inflammatory effects and the steroid-induced fat necrosis, resulting in less perineural sacrospinoso e sacrotuberoso, il più vicino possibile alla parte caudale della spina ischiatica), vengono iniettati 0,75 ml di mezzo di contrasto diluito (soluzione al $5 \%$ di Iomeron $300 \mathrm{mg} / \mathrm{ml}$, Bracco, Milano, Italia); il mezzo di contrasto circonda il fascio pudendo nello spazio interlegamentoso. Si inietta quindi una miscela di metilprednisolone acetato (1 $\mathrm{ml}$ di soluzione di Depo-Medrol $40 \mathrm{mg} / \mathrm{ml}$, Pfizer, New York, USA) e di lidocaina cloridrato $(1 \mathrm{ml}$ di soluzione al $2 \% 200 \mathrm{mg} / 10 \mathrm{ml}$, Bioindustria LIM, Novi Ligure, Italia). La lidocaina, anestetico long-acting, produce un'anestesia cutanea del territorio del nervo pudendo e fa da indicatore dell'ubicazione esatta del blocco del nervo. Il cortisonico provvede alla risposta a lungo termine sia per gli effetti anti-infiammatori degli steroidi che per la necrosi adiposa indotta dagli steroidi con riduzione dell'azione compressiva peri-neurale. Per le iniezioni a livello del canale pudendo (Fig. 3), le scansioni TC vengono effettuate all'altezza della sinfisi pubica. Il fascio pudendo è identificato medialmente al muscolo otturatore interno. Dopo aver introdotto un ago da 22-gauge con decorso verticale tramite un approccio transgluteo, si dispone l'ago a livello del tessuto adiposo posto subito lateralmente alla fascia otturatoria. Una volta valutata la corretta posizione della punta dell'ago mediante iniezione di una soluzione di 0,75 $\mathrm{ml}$ di mezzo di contrasto diluito, che dimostra il nervo pudendo all'ingresso del canale di Alcock, somministriamo localmente la miscela di anestetico e di steroide nelle stesse quantità e proporzioni della prima iniezione.

Per una valutazione dell'esito del trattamento dal punto di vista della valutazione soggettiva del paziente, a ciascuna delle donne inserite al protocollo di studio è stato 

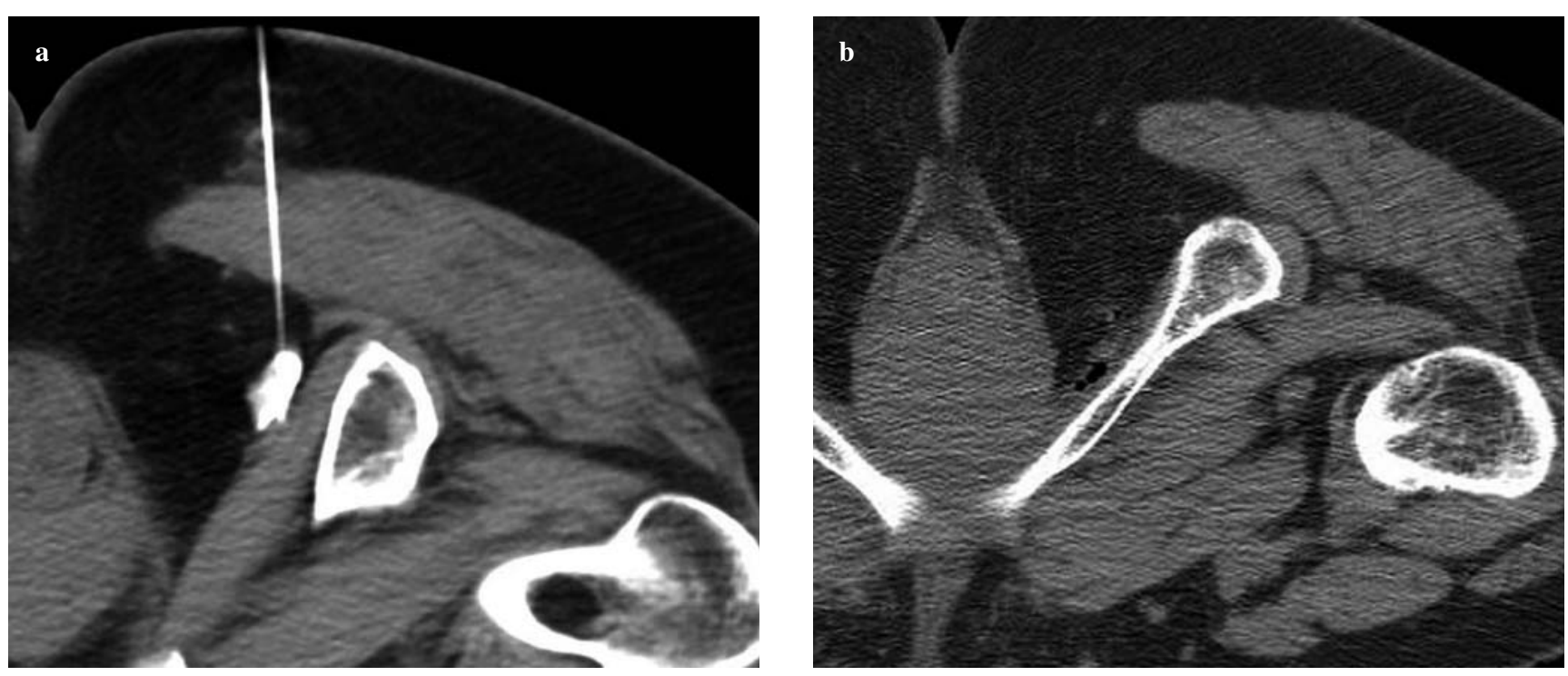

Fig. 3a The needle is placed at Alcock's canal. The contrast material shows the nerve outline. b After the needle is removed, a small quantity of air is visible at the level of Alcock's canal.

Fig. 3 a Ago posizionato in corrispondenza del canale di Alcock. Il mezzo di contrasto delimita il profilo del nervo. b Dopo rimozione dell'ago si osserva la presenza di una piccola quantità di gas a livello del canale di Alcock.

compression. For injections at the pudendal canal (Fig. 3), CT scans are obtained at the level of the pubic symphysis. The pudendal bundle is identified on the medial aspect of the obturator internus. A 22-gauge needle is inserted vertically via a transgluteal approach and placed in the fat tissue immediately lateral to the obturator fascia. Correct needle placement is checked by injecting $0.75 \mathrm{ml}$ of diluted contrast agent and visualising the pudendal nerve at the entrance of Alcock's canal. A mixture of anaesthetic and steroid in the same amounts and proportions as used for the first injection is then injected.

To obtain patients' subjective evaluation of outcome, each woman was given a questionnaire (including the VAS; pain score referred to intensity, muscular distress, muscular spasm, interference with normal daily activities) to be filled in once a week at the same hour throughout the follow-up period (from 3 to 12 months) and handed in at the monthly hospital visits. Patients were examined and interviewed every month to rate their perceived quality of life (QOL index) after treatment on a five-point scale $(1=\mathrm{QOL}$ worsened; $2=\mathrm{QOL}$ unchanged; $3=\mathrm{QOL}$ improved with occasional symptom remission; $4=\mathrm{QOL}$ improved with persistent symptom remission; 5=QOL optimal, with disappearance of pain).

\section{Results}

A total of 82 procedures were completed over 164 sessions (Table 1). In one case, the procedure had to be discontinued because the patient had respiratory insufficiency and could sottoposto un questionario relativo al VAS score (Visual Analog Pain Scale - livello di dolore riferito a intensità, distress muscolare, spasmo muscolare, interferenza con normali attività quotidiane) da compilare settimanalmente a casa, allo stesso orario del giorno per la durata del followup (variabile da 3 a 12 mesi) e riconsegnato mensilmente in ospedale. Con cadenza mensile i pazienti trattati sono stati visitati ed intervistati per ottenere un valore individuale di percezione della qualità della vita post-trattamento $(Q O L$ index) in una scala variabile da 1 (peggioramento della qualità della vita dopo il trattamento) a 5 (qualità della vita ottimale con scomparsa della sintomatologia dolorosa), con valori intermedi di 2 (qualità della vita invariata rispetto al pre-trattamento) 3 (qualità della vita migliorata con remissione saltuaria dei sintomi) e 4 (qualità della vita migliorata con remissione persistente dei sintomi).

\section{Risultati}

Sono state completate 82 procedure per 164 sessioni (Tabella 1). In un caso la procedura è stata sospesa per impossibilità della paziente a mantenere la posizione prona in relazione ad una condizione di insufficienza respiratoria; la paziente è stata pertanto esclusa dalla successiva valutazione. Nei restanti 27 casi sono state effettuate tutte le procedure (81), nei tempi e nelle modalità sopradescritte. La procedura è stata sempre eseguita senza complicanze in un periodo di tempo variabile da 20 a 30 minuti. Le infiltrazioni sono state eseguite monolateralmente, nel lato affetto dalla sintomatologia, in 26 casi su 27; solo in un caso la 
Table 2 Visual analogue score changes from baseline at $24 \mathrm{~h}^{\mathrm{a}}$

\begin{tabular}{ll}
\hline & Mean \pm standard deviation \\
\hline Activity & $-1.95 \pm 0.79$ \\
Intensity & $-1.78 \pm 0.88$ \\
Spasm & $-1.92 \pm 0.88$ \\
Distress & $-1.48 \pm 0.95$ \\
\hline
\end{tabular}

${ }^{\mathrm{a}}$ Mean and standard deviation data were collected after $24 \mathrm{~h}$ for each experimental condition. Note that a negative score indicates an improvement in symptoms

Tabella 2 Variazioni del Visual Analogue Score dalla linea di base a $24 h^{a}$

\begin{tabular}{ll}
\hline & Media $\pm D S$ \\
\hline Attività & $-1.95 \pm 0.79$ \\
Intensità & $-1.78 \pm 0.88$ \\
Spasmo & $-1.92 \pm 0.88$ \\
Distress & $-1.48 \pm 0.95$ \\
\hline
\end{tabular}

${ }^{a}$ Media e DS acquisiti a 24 h in ogni condizione sperimentale. Notare che $i$ valori negativi sono indicativi di miglioramento della sintomatologia

not tolerate the prone position. This patient was consequently excluded from the evaluation. In the remaining 27 patients, all procedures (81) were successfully completed within the timeframe and in the manner described above. All procedures were completed without complications in 20-30 min. Infiltrations were unilateral - on the symptomatic side - in 26/27 cases and bilateral in one case. No technical complications were observed.

Minor treatment complications included a burning sensation at the injection site in $12 / 27$ patients (44\%), a temporary $(<12-\mathrm{h})$ worsening of pain in $3 / 27$ patients $(11 \%)$ and transient ( $>12-\mathrm{h})$ block of the sciatic nerve in $11 / 27$ patients $(40 \%)$. Some pain at the infiltration site was reported in $26 / 27(96 \%)$ cases once the anaesthetic had worn off.

The results of the questionnaire showed a significant reduction in pain $24 \mathrm{~h}$ after treatment in $21 / 27$ cases $(77 \%)$ (Table 2), and a nonsignificant reduction in $6 / 27$ cases (activities $0.059 \pm 0.49$; intensity $-0.23 \pm 0.68$; spasm $-0.16 \pm 0.58$; distress $-1.68 \pm 0.58)$. There was a $20 \%$ or greater improvement in the QOL index in 24/27 cases (88\%) at follow-up (48\% at 3 months; $4 \%$ at 6 months; $15 \%$ at 9 months; $33 \%$ at 12 months), and less than $20 \%$ improvement in 3/27 cases.

Evaluation of pain after treatment compared with perceived pain before treatment showed a significant improvement in 25/27 cases, with a VAS (mean \pm standard deviation) of $-2.12 \pm 0.41$, with a score of 5 in six patients (22\%), a score of 4 in five $(18 \%)$ and a score of 3 in 14 $(52 \%)$. Two patients reported no benefit following treatment (VAS -0.78 \pm 0.11$)$. procedura è stata eseguita bilateralmente. Non sono state rilevate complicanze tecniche della procedura.

Complicanze minori del trattamento sono state il bruciore a livello del sito di iniezione (12/27 pazienti, 44\%), temporaneo $(<12$ ore) peggioramento della sintomatologia algica (3/27 pazienti, 11\%), blocco transitorio (>12 ore) del nervo sciatico (11/27 pazienti, 40\%). Una dolenzia nelle sedi della infiltrazione, una volta scomparso l'effetto dell'anestetico, è stata riscontrata in 26 casi su 27 (96\%).

Il questionario a cui sono state sottoposte le pazienti ha fornito le seguenti valutazioni. A 24 ore dalla procedura in 21 su 27 casi (77\%) è stata riferita una riduzione significativa del dolore rispetto alla baseline (Tabella 2), mentre in 6 su 27 casi il dolore si è ridotto in modo non significativo

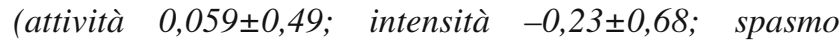
$-0,16 \pm 0,58$; distress $-1,68 \pm 0,58)$. Un miglioramento del $20 \%$ o più del QOL index è stato riferito in 24 su 27 casi (88\%) rispetto al relativo follow-up (48\% a 3 mesi; $4 \%$ a 6 mesi; $15 \%$ a 9 mesi; $33 \%$ a 12 mesi) mentre in 3 casi su 27 è stato inferiore al $20 \%$.

La valutazione del dolore al termine del trattamento rispetto alla percezione del dolore prima dell'esecuzione del trattamento, ha riportato in 25 casi su 27 un miglioramento significativo con un VAS (media \pm deviazione stan-

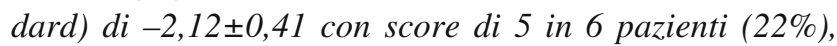
score 4 in 5 pazienti (18\%) e score 3 in 14 (52\%). In 2 casi su 27 non è stato riferito alcun beneficio a distanza dal trat-

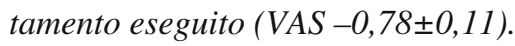

\section{Discussione}

L'eziologia del dolore ano-perineale cronico in assenza di una identificabile causa urologica, ginecologica o proctologica è frequente e di difficile individuazione. Numerose sindromi sono state messe in causa per spiegare questo tipo di dolore, come ad esempio la coccigodinia, la proctalgia fugace o la sindrome del muscolo elevatore dell'ano.

In assenza di imaging patognomonico, reperti laboratoristici ed elettrofisiologici, la diagnosi di nevralgia del pudendo rimane clinica. Semplici recenti criteri utili alla identificazione clinica della nevralgia del pudendo dovuta ad intrappolamento del nervo sono $i$ cinque criteri di Nantes [9]: (1) dolore nel territorio del nervo pudendo: dall'ano verso il pene o il clitoride;(2) dolore accentuato dalla posizione seduta; (3) dolore che non risveglia il paziente di notte; (4) sintomatologia algica in assenza di perdita di sensibilità; (5) miglioramento del dolore dopo blocco anestetico del nervo.

Criteri di esclusione della neuropatia sono dolore puramente coccigeo, gluteo o ipogastrico, dolore esclusivamente parossistico, prurito, reperti di imaging che spiegano la sintomatologia. Tuttavia la presenza di una sintomatologia 


\section{Discussion}

Chronic anoperineal pain in the absence of any identifiable urological, gynaecologic or proctological cause is common and its aetiology difficult to ascertain. Numerous syndromes have been cited to explain this type of pain, such as coccygodynia, proctalgia fugax or levator ani syndrome.

In the absence of pathognomonic imaging, laboratory and electrophysiological findings, the diagnosis of pudendal neuralgia remains clinical. Simple criteria for the clinical demonstration of pudendal neuralgia due to nerve entrapment are the following (Nantes criteria) [9]: (1) pain in the anatomical area supplied by the pudendal nerve (from the anus to the penis or clitoris); (2) pain worsens when patient is sitting; (3) pain never causes the patient to wake in the night; (4) no sensory loss is found on clinical examination; (5) pain improves after anaesthetic nerve block.

Exclusion criteria for neuropathy are purely coccygeal, gluteal or hypogastric pain; exclusively paroxysmal pain; pruritus; and imaging findings accounting for the symptoms. However, the presence of pain in the area supplied by the pudendal nerve should always arouse suspicion of pudendal neuralgia related to strain and compression. Compression is more likely if the pain worsens upon sitting and is relieved upon standing or lying.

Surgical decompression and transposition of the pudendal nerve is an effective procedure for pudendal neuralgia unresponsive to other treatments [15]. Long-term effectiveness is, however, undermined by late recurrence due to irreversible nerve damage; incomplete release of the nerve, especially in the case of entrapment in the distal Alcock's canal; and the appearance of postsurgical perineural fibrosis. Diagnostic imaging plays an important role in excluding other conditions that may simulate anoperineal pain and in providing guidance during nerve infiltration.

As in other entrapment syndromes, nerve infiltration at the site of compression has a dual role: diagnostic when performed with an anaesthetic, and therapeutic when performed with corticosteroids. Treatment of pudendal neuropathy with corticosteroid and anaesthetic infiltration is not new, with pudendal nerve block via a transperineal approach having been first described by Muelener in 1908 [14]. In gynaecology, the transvaginal approach is now well established, although it is associated with spasms of the pelvic muscles and limited accuracy in needle placement.

Percutaneous treatment may be performed under CT [14, 16, 17], fluoroscopic [18] or EMG [13] guidance. Pudendal nerve block with conventional fluoroscopic guidance has become popular in clinical practice owing to the easy identification of anatomical landmarks [18, 19], with placement of the needle tip near the apex of the iliac crest. Nonetheless, the pudendal nerve courses in an anatomical plane formed by the sacrospinous and sacrotuberous ligament dolorosa nel territorio di innervazione del nervo pudendo deve sempre far considerare la presenza di una nevralgia dello stesso nervo, sia da allungamento sia da compressione; la compressione è più probabile come causa del dolore quando questo peggiora con la posizione seduta mentre descresce in ortostatismo e nella posizione sdraiata.

La chirurgia di decompressione e trasposizione del nervo pudendo rappresenta una tecnica efficace nel trattamento della nevralgia del pudendo non responsiva ad altri trattamenti [15]. L'efficacia a lungo termine risulta tuttavia inficiata dalla ricomparsa tardiva del dolore a causa di danneggiamento irreversibile del nervo, incompleto rilascio dello stesso soprattutto in caso entrapment a livello della parte distale del canale di Alcock e dalla comparsa di fibrosi peri-neurale post-chirurgica. La diagnostica per immagini riveste un ruolo importante non nell'accertamento della patologia in se stessa quanto nella esclusione delle condizioni che possono simulare il dolore ano-perineale e come guida nell'infiltrazione del nervo.

Come nelle altre sindromi da intrappolamento l'infiltrazione del nervo nella sede della compressione ha un duplice effetto: diagnostico quando essa viene effettuata con anestetico e terapeutico quando vengono iniettati nella sede dei cortisonici. Il trattamento della neuropatia del pudendo mediante infiltrazione con cortisonici ed anestetici non è una terapia nuova; il blocco del nervo pudendo con approccio transperineale è stato descritto per la prima volta da Muelener nel 1908 [14]. In campo ginecologico è riconosciuto l'approccio transvaginale. Tuttavia tale tipo di approccio può comportare uno spasmo della muscolatura pelvica ed una scarsa precisione nel posizionamento dell'ago.

La terapia percutanea può essere eseguita sotto guida TC [14, 16, 17], fluoroscopica [18] oppure impiegando una guida elettromiografica [13]. La tecnica di blocco del nervo pudendo con guida fluoroscopica convenzionale ha guadagnato popolarità nella pratica clinica per il facile riconoscimento dei reperi anatomici [18, 19], posizionando la punta dell'ago nella adiacenza dell'apice della cresta iliaca. Tuttavia il nervo pudendo decorre in un piano anatomico tra il legamento sacrospinoso e sacrotuberoso (piano interligamentoso) che non è visualizzabile in fluoroscopia. La guida ecotomografica per il blocco percutaneo del nervo pudendo a livello della spina ischiatica è una tecnica semplice e ripetibile [20, 21]. L'ecografia garantisce una diretta visualizzazione dei reperi anatomici in diretta contiguità con il nervo pudendo quali la spina ischiatica, l'arteria pudenda interna, ed i legamenti sacrospinoso e sacrotuberoso. È possibile visualizzare in real-time la diffusione della soluzione iniettata. Non si impiegano radiazioni ionizzanti. Svantaggi del centraggio ecografico, sono relativi alla difficile visualizzazione del nervo pudendo $(12 \%$ dei casi in una recente casistica di Rofaeel et al. [22]) le cui 
(interligamentous plane), which fluoroscopy is unable to visualise. US-guided percutaneous pudendal nerve block at the level of the ischial spine is a simple and reproducible procedure [20, 21]. US ensures direct visualisation of anatomical landmarks immediately contiguous to the pudendal nerve, such as the ischial spine, the internal pudendal artery and the sacrospinous and sacrotuberous ligaments. Spread of the injected solution can be observed in real time, and no ionising radiation is employed. The disadvantages of US are related to the difficulty in visualising the pudendal nerve (12\% in a recent series [22]), which measures 4-6 mm at the ischial spine [23], the sacrotuberous ligament and the pudendal artery, which may be confused with the inferior gluteal artery, with consequent frequent sciatic nerve block. However, at the level of the ischial spine, in $30 \%-40 \%$ of cases, the pudendal nerve shows anatomical variants, with two or three nerve trunks [7] covered by dense connective and/or fat tissue [22], resulting in poor sonographic conspicuity and limited response to nerve stimulation. The depth of the ischial spine from the cutaneous plane is usually $>7 \mathrm{~cm}$. This requires intraoperative fluoroscopy to confirm correct needle placement and solution delivery, with a US/fluoroscopy concordance of $82 \%$. Nerve stimulation (graded electrical stimulation) to confirm correct placement of the US-guided needle does not appear to be an absolute technique because of the size of the nerve at the level of the interligamentous space $[24,25]$. Perineural injection may cause the appearance of short-term ENMG changes, even when pain has resolved.

CT-guided infiltration is a problem-solving technique that ensures correct needle placement at the site of passage of the pudendal nerve close to the ischial spine and at the entrance to Alcock's canal. However, it should be considered that the reported timing and outcomes of procedures vary widely. Thoumas et al. [19] reported on 200 infiltrations, with two or three injections of $5 \mathrm{ml}$ of lidocaine and $1.5 \mathrm{ml}$ of corticosteroids, but they failed to describe the final outcome in terms of pain relief. McDonald et al. [16] achieved an improvement of symptoms in three-quarters of a population of 26 patients treated with five infiltrations repeated once a month. Benson and Griffis [14] obtained an improvement of symptoms in $31 \%$ of cases (12/38) by injecting $1 \mathrm{cc}$ of triamcinolone and $9 \mathrm{cc}$ of lidocaine and performing up to three injections 6 weeks apart. Furthermore, they reported exacerbation of symptoms for 7-10 days following the injection, which was, however, performed under EMG guidance.

Assessment of outcomes may prove difficult owing to the subjective nature of the evaluation of symptom improvement. The scale adopted in our study allows for a more systematic evaluation of the evolution of symptoms, as it distinguishes between the benefits deriving from the individual injections from the final overall benefits and includes an assessment dimensioni a livello della spina ischiatica sono di 4-6 mm [23], del legamento sacrotuberoso, della arteria pudenda, facilmente confusa con la glutea inferiore con conseguente frequente blocco del nervo sciatico. Sempre a livello della spina ischiatica, il nervo pudendo nel 30\%-40\% dei casi presenta varianti anatomiche con 2 o 3 tronchi nervosi [7], rivestiti da connettivo denso elo da tessuto adiposo [22], con conseguente ridotta visibilità ecografia del nervo nonché scarsa risposta alla stimolazione nervosa. La profondità della spina ischiatica dal piano cutaneo è comunemente $>7 \mathrm{~cm}$, con conseguente necessità intra-procedurale di ricorrere alla fluoroscopia per confermare il centraggio dell'ago e la somministrazione della soluzione, con una concordanza ecografia/fluoroscopia dell'82\%. La stimolazione nervosa (stimolazione elettrica graduata) per confermare il posizionamento dell'ago eco-guidato non appare una tecnica assoluta, a causa delle dimensioni del nervo a livello dello spazio interlegamentoso [24, 25]. L'iniezione perineurale può determinare la comparsa di alterazioni ENMG a breve termine, anche quando la sintomatologia dolorosa sia risolta.

L'infiltrazione TC guidata è una tecnica "problem solving" garantendo il corretto posizionamento dell'ago nella sede di passaggio del nervo pudendo in prossimità della spina ischiatica e a livello dell'ingresso nel canale di Alcock. Tuttavia è necessario tenere conto come il timing delle iniezioni ed i risultati riportati dagli altri autori siano diversi tra loro; Thoumas et al. [19] eseguendo 2 o 3 iniezioni di $5 \mathrm{ml}$ di lidocaina e di 1,5 $\mathrm{ml}$ di cortisonico riporta una casistica di 200 infiltrazioni, ma non specifica il risultato finale delle stesse riguardo il sollievo dalla sintomatologia. Mc Donald et al. [16] riporta su di una casistica di 36 pazienti un miglioramento della sintomatologia nei $3 / 4$ dei casi; la sua tecnica consiste in 5 infiltrazioni ripetute a distanza di 30 giorni l'una dall'altra. Benson e Griffis [14] riferisce un miglioramento dei sintomi nel $31 \%$ dei casi (12/38) iniettando 1 cc di triamcinolone e 9 cc di lidocaina ed eseguendo un massimo di 3 iniezioni a distanza di 6 settimane; inoltre riporta un'esacerbazione dei sintomi per $i$ successivi 7-10 giorni a seguito dell'iniezione, eseguita però sotto guida EMG e non mediante imaging.

La valutazione dei risultati appare senza dubbio difficile, essendo molto soggettiva la valutazione del miglioramento sintomatologico. La scala da noi adottata permette una valutazione più sistematica dell'evoluzione dei sintomi, distinguendo il beneficio di ciascuna iniezione da quello finale complessivo e valutando anche la capacità del soggetto di svolgere normalmente la sua attività quotidiana.

In tutte le casistiche riportate non sono mai riferiti insuccessi tecnici della procedura; nell'iniezione in corrispondenza della spina ischiatica occorre tuttavia prestare attenzione a non spostare l'ago troppo lateralmente, pena una 
of the subject's ability to carry out daily activities.

None of the previous series reported on any technical failures. However, with regard to injections at the ischial spine level, it is important to avoid moving the needle too laterally so as not to cause sciatic nerve block. Secondary complications include haematoma at the injection site, pain worsening for a few days and transient nerve blocks lasting hours.

As shown in our experience, perineural injection of the pudendal nerve is to be considered a safe procedure that is free of significant complications. In the case of suspected pudendal nerve entrapment syndromes, we believe that CTguided infiltration of impingement sites can and should be performed, partly in consideration of the fact that other approaches - conservative therapy, decompressive surgery and neuromodulation [13] - fail to provide consistent and long-lasting results. conseguente analgesia del nervo sciatico. Le complicanze secondarie possono includere l'ematoma nella sede dell'iniezione, il peggioramento del dolore della durata di alcuni giorni ed il blocco transitorio del nervo per alcune ore.

I risultati da noi presentati sono indicativi comunque della efficacia terapeutica e della mancanza di complicanze. L'iniezione perineurale del nervo pudendo è da considerarsi una procedura sicura, scevra da complicanze significative. Nel caso delle sospette sindromi da intrappolamento del nervo pudendo riteniamo che l'infiltrazione TC guidata delle sedi di conflitto possa e debba essere sempre eseguita, considerando anche che gli altri approcci terapeutici, terapia conservativa, chirurgia decompressiva e neuromodulazione [13] non offrono risultati costanti e duraturi.

Conflict of interest statement The authors declare that they have no conflict of interest to the publication of this article.

\section{References/Bibliografia}

1. Mathias SD, Kuppermann M, Liberman RF et al (1996) Chronic pelvic pain: prevalence, health-related quality of life, and economic correlates. Obstet Gynecol 87:321-327

2. Schaeffer AJ (2004) Etiology and management of chronic pelvic pain syndrome in men. Urology 63:75-84

3. Wesselman U, Burnett AL, Heinberg LJ (1997) The urogenital and rectal pain syndromes. Pain 73:269-294

4. Grigorescu BA, Lazarou G, Olson TR (2008) Innervation of the levator ani muscles: description of the nerve branches to the pubococcygeus, iliococcygeus, and puborectalis muscles. Int Urogynecol J 19:107-116

5. Hough DM, Wittenberg KH, Pawlina W et al (2003) Chronic perineal pain caused by pudendal nerve entrapment: anatomy and CT-guided perineural injection technique. AJR. American journal of roentgenology 181:561-567

6. Labat JJ, Riant T, Robert R et al (2008)

Diagnostic criteria for pudendal neuralgia by pudendal nerve entrapment (Nantes criteria). Neurourol Urodyn 27:306-310

7. Lefaucher JP, Labat JJ, Amarenco G (2007) What is the place of electroneuromyographic studies in the diagnosis and management of pudendal neuralgia related to entrapment syndrome? Neurophysiol Clin 37:223-228
8. Amarenco G, Lanoe Y, Perrigot M et al (1987) A new canal syndrome: compression of the pudendal nerve in Alcock's canal or perinal paralysis of cyclists. Presse Med 16:399

9. Labat JJ, Robert R, Bensignor M et al (1990) Les névralgies du nerf pudendal (honteux interne). Considérations anatomo-cliniques et perspectives thérapeutiques. J Urol 96:239-244

10. Boisson J, Debbasch L, Bensaude A (1966) Les algies ano-rectales essentielles. Arch Fr Mal Appar Dig 55:3-24

11. Amarenco G, Lanoe Y, Ghnassia RT et al (1988) Alcock's canal syndrome and perineal neuralgia. Rev Neurol 144:523-526

12. Robert R, Prat-Pradal D, Labat JJ et al (1998) Anatomic basis of chronic perineal pain: role of the pudendal nerve. Surg Radiol Anat 20:93-98

13. Amarenco G, Le Cocquen-Amarenco A, Kerdraon J et al (1991) Perineal neuralgia Presse Med 20:71-74

14. Benson JT, Griffis K (2005) Pudendal neuralgia, a severe pain syndrome. Am J Obstet Gynecol 192:1663-1668

15. Shafik A, el-Sherif M, Youssef A et al (1995) Surgical anatomy of the pudendal nerve and its clinical implications. Clin Anat 8:110-115
16. Mc Donald JS, Spigos DG (2000) Computed tomography-guide pudendal block for treatment of pelvic pain due to pudendal neuropathy. Obstet Gynecol 95:306-309

17. Robert R, Labat JJ, Bensignor M (2005) Decompression and transposition of the pudendal nerve in pudendal neuralgia: a randomized controlled trial and long-term evaluation. Eur Urol 47:403-408

18. Calvillo O, Skaribas IM, Rockett C (2000) Computed tomography-guided pudendal nerve block. A new diagnostic approach to long-term anoperineal pain: a report of two cases. Reg Anesth Pain Med 25:420-423

19. Thoumas D, Leroi AM, Mauillon J et al (1999) Pudendal neuralgia: CT-guided pudendal nerve block technique. Abdom Imaging 24:309-312

20. Abdi S, Shenouda P, Patel N et al (2004) A novel technique for pudendal nerve block. Pain Physician 7:319-322

21. Choi SS, Lee PB, Kim YC (2006) Carm-guided pudendal nerve block: a new technique. Int J Clin Pract 60:553-556

22. Rofaeel A, Peng P, Louis I (2008) Feasibility of real-time ultrasound for pudendal nerve block in patients with chronic perineal pain. Reg Anesth Pain Med 33:139-145 
23. Kovacs P, Gruber H, Piegger J (2001) New, simple, ultrasound-guided infiltration of the pudendal nerve: ultrasonographic technique. Dis Colon Rectum 44:1381-1385
24. Mahakkanukrauh P, Surin P, Vaidhayakarn P (2005) Anatomical study of the pudendal nerve adjacent to the sacrospinous ligament. Clin Anat 18:200-205
25. Gruber H, Kovacs P, Piegger J ( 2001) New, simple, ultrasound-guided infiltration of the pudendal nerve: topographic basics. Dis Colon Rectum 44:1376-1380 